\title{
Sebaran Spasial dan Temporal Klorofil-a di Perairan Teluk Semarang
}

\author{
Arya Muhammad ${ }^{*}$ Jarot Marwoto, Kunarso, Lilik Maslukah, dan Sri Yulina Wulandari \\ Departemen Oseanografi, Fakultas Perikanan dan Ilmu Kelautan, Universitas Diponegoro \\ Jl. Prof. Soedarto, SH, Tembalang, Semarang, Jawa Tengah, 50275 \\ Email : *aryamuhammad@students.undip.ac.id
}

\begin{abstract}
Abstrak
Teluk Semarang merupakan teluk terbesar di pantai utara Jawa Tengah dan tercatat terdapat 29 aliran sungai bermuara ke teluk ini. Banyak aktivitas manusia seperti industri, pemukiman dan pelabuhan yang bermuara di teluk ini. Aktvitas yang berlangsung di Teluk Semarang berpotensi mencemari perairan dan mengakibatkan perubahan terhadap faktor fisika dan kimia perairan. Hal tersebut berdampak langsung pada kelimpahan dan distribusi klorofil-a. Tujuan penelitian ini adalah mengkaji sebaran konsentrasi klorofil-a secara Spasial dan Temporal di perairan Teluk Semarang dan mengkaji keterkaitan-nya dengan parameter lainya. Citra yang digunakan untuk analisa Klorofil-a adalah citra Aqua MODIS beresolusi 4 km dan data pelengkap yaitu yaitu kecepatan dan arah angin, SPL, salinitas, curah hujan dan TSS. Penelitian ini memanfaatkan Sistem Informasi Grafis. Hasil pengolahan citra menujukan bahwa Nilai rerata bulanan Klorofil-a di perairan Teluk Semarang berkisar antara 1,85-4,27 mg/m $\mathrm{m}^{3}$, Daerah dengan Klorofil-a tinggi umum nya berada pada sisi selatan Teluk Semarang. Klorofil-a memiliki korelasi bivariate yang kuat dan berbanding lurus dengan TSS $(0,743)$, secara kuat berbanding lurus terhadap kecepatan angin $(0,456)$, curah hujan $(0,506)$ dan secara kuat berbanding terbalik dengan suhu $(-0,665)$.
\end{abstract}

Kata kunci : Klorofil-a, Aqua-MODIS, Teluk Semarang

\begin{abstract}
Semarang Bay is the largest bay on the northern coast of Central Java with 29 rivers that flow into this bay. Many human activities such as industry, settlements and ports that empties into this bay. The activities that take place in Semarang Bay are probably water factors and changes to physics and waters. This has a direct impact on and distribution of chlorophyll-a. The purpose of this study was to examine the spatial and temporal distribution of chlorophyll concentration in the waters of Semarang Bay and to examine its relationship with other parameters. The image used for Chlorophyll-a analysis is an Aqua MODIS image with a resolution of $4 \mathrm{~km}$ and complementary data, namely wind speed and direction, SST, salinity, rainfall and TSS. This research utilizes Graphic Information System. The results of image processing shows, that the monthly mean value of chlorophyll-a in Semarang Bay, ranges from 1.85-4.27 mg/m3, Areas with high chlorophyll-a are generally located on the south side of Semarang Bay. Chlorophylla has a bivariate correlation that is strong and directly proportional to TSS (0.743), strongly proportional to wind speed (0.456), rainfall (0.506) and strongly inversely proportional to temperature (-0.665).
\end{abstract}

Keywords : Chlorophyll-a, Aqua-MODIS, Semarang Bay

\section{PENDAHULUAN}

Teluk Semarang merupakan perairan yang berada di pantai utara Jawa yang terbentang dari Kabupaten Kendal hingga Kabupaten Demak. Jarak antara pantai Tanjung Korowelang Kabupaten Kendal ke pantai Morodemak Kabupaten Demak sekitar 23 mil dengan luas perairan kurang lebih 170,2 km2. Perairan Teluk Semarang masih menyimpan potensi sumberdaya ikan karena dukungan posisi geografis daerah tropis yang dapat menyumbang kesuburan perairanKondisi Perairan Teluk Semarang saat ini menandakan tingkat kesuburan perairan tidak begitu baik karena pada perairan tersebut semakin mendapat tekanan kontaminasi 
limbah organik dan anorganik dari semakin berkembangnya daerah pemukiman dan industri sepanjang pesisir Teluk Semarang (Adji, 2008)

Berbagai penelitian mengenai klorofil-a perairan telah dilakukan di beberapa daerah di Teluk Semarang, namun umumnya dilakukan di daerah pesisir dengan cakupan daerah penelitian yang relatif kecil . Sedangkan ketersediaan informasi distribusi kesuburan dengan cakupan daerah yang lebih luas, dalam hal ini mencakup seluruh daerah Teluk Semarang masih terbatas. Maka diperlukan suatu kajian sebaran kesuburan baik secara spasial dan temporal dengan daerah penelitian yang lebih luas, untuk memahami kondisi kesuburan Teluk Semarang di setiap musimnya.

\section{MATERI DAN METODE}

Data primer yang digunakan adalah data citra Aqua MODIS Klorofil-a klimatologi bulanan sepanjang tahun 2017-2018 beresolusi $4 \mathrm{~km}$ x $4 \mathrm{~km}$. Data pendukung berupa data suhu permukaan laut, Salinitas, Total Suspended Solids (TSS), curah hujan, arah dan kecepatan angin.

Metode penelitian yang digunakan adalah metode deskriptif dengan pendekatan analisis kuantitatif. Metode deskriptif adalah metode yang digunakan untuk mendapatkan deskripsi atau gambaran mengenai suatu kejadian yang dikaji dalam waktu dan tempat tertentu (Hadi, 1987). Menurut Sarwono (2006), penelitian dengan pendekatan kuantitatif bertujuan untuk menguji sebuah teori, membangun fakta, menunjukkan hubungan antar variabel, memberikan suatu deskripsi statistik dan meramalkan.

Dalam menentukan lokasi studi terdapat metode bernama area sampling. Teknik sampling ini digunakan untuk menentukan sampel bila objek yang akan diteliti atau sumber data sangat luas (Sugiyono, 2008). Lingkup area penelitian meliputi pantai sepanjang $104 \mathrm{~km}$ yang terbentang dari muara sungai Bodri, Kabupaten Kendal sampai muara sungai Wulan, Kabupaten Demak, dengan batas terluar teluk meliputi garis lurus yang terbentang dari titik LS 6 $6^{\circ} 43^{\prime} 21,32^{\prime \prime}$ - BT 110 $33^{\prime} 14,43^{\prime \prime}$ sampai LS 6 $500^{\prime} 48,97^{\prime \prime}$ - BT $110^{\circ}$ 10'39,39”.

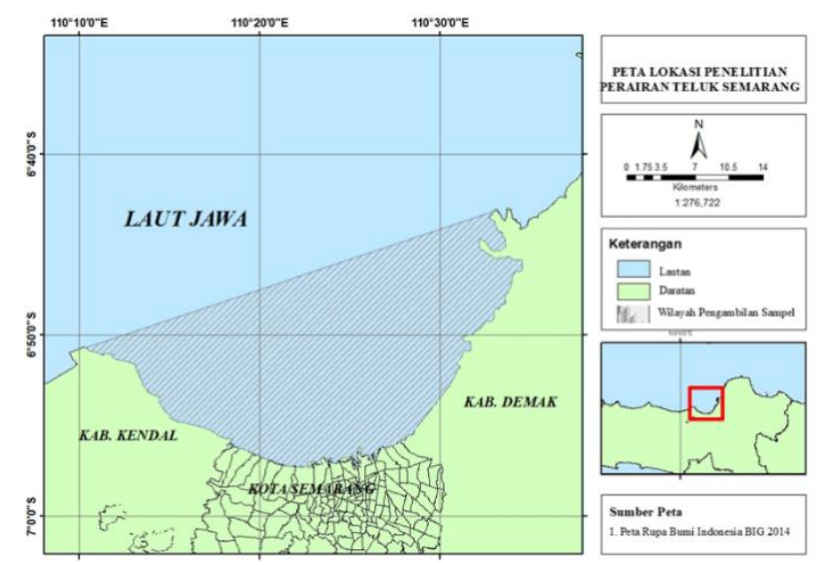

Gambar 1. Luasan Lokasi Penelitian

\section{Analisis Data Citra Aqua MODIS Klorofil-a dan Suhu Permukaan Laut}

Data suhu permukaan laut dan Klorofil-a yang diunduh dari http://oceacolor.gsfc.nasa.gov merupakan data citra bulanan. Data di olah dengan software SeaDAS, dilakukan tahap reprojeksi selanjutnya dilakukan masking wilayah sesuai luasan lokasi penelitian. Data suhu di ekstrasi dalam bentuk teks yang kemudian diolah pada program Microsoft Excel untuk mencari rata-rata suhu bulanan dan klorofil-a dalam 2 tahun serta mencari kadarnya dalam rerata bulanan. 
Data rata- rata suhu bulanan dan klorofil-a selanjutnya diolah dengan software ArcMap. Data suhu berupa titik yang tersebar dalam 31 titik koordinat diinterpolasi dengan menggunakan IDW Spatial Analyst. Interpolasi adalah proses memprediksi nilai pada suatu titik yang bukan merupakan titik sampel, berdasarkan pada nilai-nilai dari titik-titik di sekitarnya yang berkedudukan sebagai sampel. Metode Inverse Distance Weighted (IDW) merupakan metode deterministik yang sederhana dengan mempertimbangkan titik disekitarnya. Asumsi dari metode ini adalah nilai interpolasi akan lebih mirip pada data sampel yang dekat daripada yang lebih jauh (Pramono, 2005)

\section{Analisis Data Salinitas}

Salinitas menggunakan data dari satelit Soil Moisture Ocean Salinity (SMOS) yang diunduh dari situs http://marine.copernicus.eu. Data salinitas yang diunduh merupakan data yang direkam selama 2 tahun yaitu tahun 2017 hingga tahun 2018, dengan resolusi $13 \mathrm{~km}$. Data citra diolah dengan software SeaDAS, dilakuan tahap reprojeksi dan tahap kedua dilakukan masking wilayah sesuai luasan lokasi penelitian. Data salinitas di ekstrasi dalam bentuk teks yang kemudian diolah pada program Microsoft Excel untuk mencari rata-rata salinitas bulanan serta mencari nilai terendah dan tertinggi salinitas setiap 1 bulan. Data salinitas bulanan selanjutnya di olah dengan software ArcMap. Data salinitas yang berupa titik-titik yang tersebar dalam 8 titik koordinat diinterpolasi dengan menggunakan IDW Spatial Analyst.

\section{Analisis Data TSS}

Perhitungan total suspended solids citra Sentinel-2 MSI diolah menggunakan C2RCC Processor dengan perangkat lunak SNAP dari ESA. Dalam pengukuran TSS, Band yang digunakan adalah Band 2 (490 $\mathrm{nm}$ ), Band 3 ( $560 \mathrm{~nm}$ ), B4( $665 \mathrm{~nm}$ ) dan Band 8 ( $842 \mathrm{~nm}$ ) yang memiliki resolusi gambar sebesar $10 \mathrm{~m}$. Band tersebut lalu diolah menggunakan Algoritma untuk menentukan nilai konsentrasi dari sebaran TSS.Berikut ini dapat dilihat algoritma (Budhiman et al., 2004) :

Keterangan

TSS

\section{TSS $(\mathrm{mg} / \mathrm{L})=8,1429 \times \exp (2,207 \times$ Red Band $)$}

Red Band : Nilai reflektan band merah.

\section{Analisis Data Angin}

Data angin diekstrak kemudian diolah menggunakan software ArcGIS. Data angin diolah memiliki resolusi sebesar $0,25^{\circ} \times 0,25^{\circ}$. Data angin berupa kecepatan total dan arah total, yang diolah menggunakan software SeaDAS 7.4 untuk mengekstrak data ke dalam bentuk Microsoft Excel dan dapat diketahui komponen $\mathrm{u}$ dan $\mathrm{v}$ kemudian dihitung kecepatan angin menggunakan persamaan :

$$
V=\sqrt{ } u^{2}+v^{2}
$$

dimana

$\mathrm{V} \quad$ : kecepatan angin total $(\mathrm{m} / \mathrm{s})$

$\mathrm{u} \quad$ : komponen angin dalam arah bujur (Timur-Barat) $(\mathrm{m} / \mathrm{s})$

$\mathrm{v} \quad$ : komponen angin dalam arah lintang (Utara-Selatan) $(\mathrm{m} / \mathrm{s})$

Data yang diolah dari Microsoft Excel kemudian diolah dengan software ArcGIS untuk menghasilkan sebuah gambar yang dapat menunjukan pola distribusi angin setiap bulan. 


\section{HASIL DAN PEMBAHASAN}

\section{Nilai Parameter secara Temporal}

Nilai rerata tertinggi Klorofil-a terjadi pada bulan Desember berkisar antara 3,13-5,37 mg/m dengan rerata sebesar $4,27 \mathrm{mg} / \mathrm{m}^{3}$, yang terjadi pada musim barat. Bersamaan dengan nilai variabilitas rerata SPL yang relatif sedang yaitu berkisar antara $29,57-32,16{ }^{\circ} \mathrm{C}$ dengan rerata sebesar $30,21{ }^{\circ} \mathrm{C}$, nilai variabilitas TSS yang relatif tinggi berkisar 7,44 - 165,39 mg/l dengan rerata sebesar 53,79 mg/l. Nilai rerata terendah Klorofil-a terjadi pada bulan Agustus yaitu berkisar antara $0,73-3,69 \mathrm{mg} / \mathrm{m} 3$ dengan rerata konsentrasi sebesar $1,85 \mathrm{mg} / \mathrm{mg} 3$, yang terjadi pada akhir musim timur. Bersamaan dengan nilai variabilitas rerata nilai variabilitas TSS yang juga terendah yaitu berkisar antara 5,92 - 68,31 mg/l dengan rerata sebesar 23,95 mg/l, dan nilai variabilitas rerata kecepatan angin yang relatif rendah sebesar 1,88 m/s.

Tabel 1. Nilai variabilitas Klorofil-a, SPL, Salinitas, Kecepatan Angin, TSS dan Curah Hujan

\begin{tabular}{|c|c|c|c|c|c|c|c|}
\hline \multirow[t]{13}{*}{ Nilai } & Bulan & $\begin{array}{l}\text { Klorofil-a } \\
\left(\mathrm{mg} / \mathrm{m}^{3}\right)\end{array}$ & $\begin{array}{l}\text { SPL } \\
\left({ }^{\circ} \mathrm{C}\right)\end{array}$ & $\begin{array}{l}\text { Salinitas } \\
(\%)\end{array}$ & $\begin{array}{l}\text { Kecepatan } \\
\text { Angin } \\
(\mathrm{m} / \mathrm{s})\end{array}$ & $\begin{array}{l}\text { Rerata } \\
\text { TSS } \\
(\mathrm{mg} / \mathrm{l})\end{array}$ & $\begin{array}{l}\text { Curah Hujan } \\
(\mathrm{mm})\end{array}$ \\
\hline & Januari & 2,95 & 30,36 & 32,21 & 3,14 & 56,72 & 9,65 \\
\hline & Februari & 3,87 & 29,77 & 32,03 & 3,13 & 38,41 & 19,95 \\
\hline & Maret & 2,82 & 30,70 & 31,39 & 1,33 & 35,38 & 7,35 \\
\hline & April & 2,46 & 30,94 & 31,51 & 1,54 & 50,14 & 8,85 \\
\hline & Mei & 3,33 & 30,49 & 31,89 & 2,11 & 26,48 & 2,33 \\
\hline & Juni & 2,90 & 30,05 & 31,92 & 2,11 & 29,99 & 2,53 \\
\hline & Juli & 2,52 & 29,39 & 32,03 & 2,17 & 28,88 & 0,44 \\
\hline & Agustus & 1,85 & 29,33 & 32,33 & 1,88 & 23,95 & 0,02 \\
\hline & September & 2,21 & 29,84 & 32,55 & 1,46 & 46,22 & 1,05 \\
\hline & Oktober & 1,89 & 30,82 & 32,51 & 1,30 & 35,83 & 7,67 \\
\hline & November & 2,18 & 31,39 & 32,78 & 1,01 & 39,42 & 8,18 \\
\hline & Desember & 4,27 & 30,21 & 32,49 & 1,59 & 53,79 & 8,61 \\
\hline
\end{tabular}

\section{Klorofil-a secara Spasial}

Konsentrasi klorofil-a mencapai nilai rerata tertinggi-nya dengan kisaran konsentrasi sebesar 3,13 $5,37 \mathrm{mg} / \mathrm{m}^{3}$ pada awal musim barat yaitu di bulan Desember. Nilai konsentrasi terbesar berada pada sisi barat Teluk Semarang yaitu pada perairan kecamatan Patebon dan kota Kendal. Di daerah tersebut terdapat dua sungai yang bermuara ke laut yaitu Sungai Blorong dan Sungai Kendal, dengan konsentrasi klorofil-a berkisar antara 4,5- $5 \mathrm{mg} / \mathrm{m}^{3}$. Konsentrasi klorofil-a terendah yaitu pada bulan Agustus dengan konsentrasi berkisar antara $0,73-3,69 \mathrm{mg} / \mathrm{m} 3$ dengan konsentrasi tertinggi berada pada sisi selatan Teluk Semarang, dengan daerah sepanjang pesisir kecamatan Sayung sampai Tugu dengan konsentrasi klorofil-a berkisar antara $2,5-3,5 \mathrm{mg}^{3}$. 


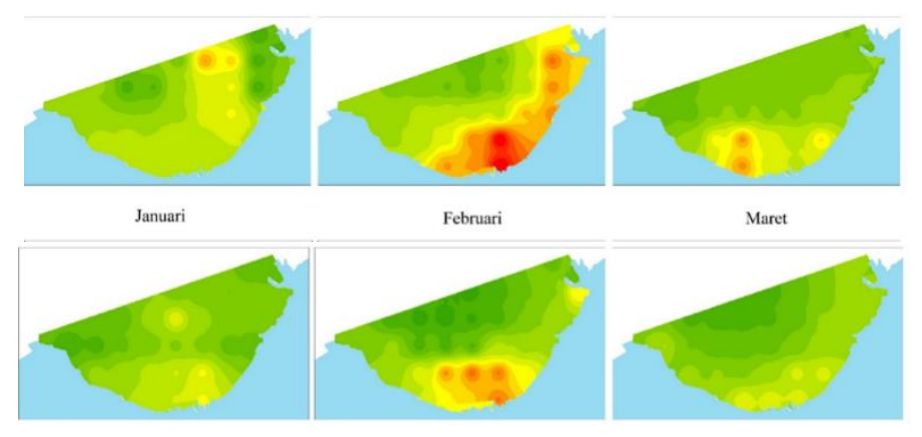

April $\quad$ Mei

Juni

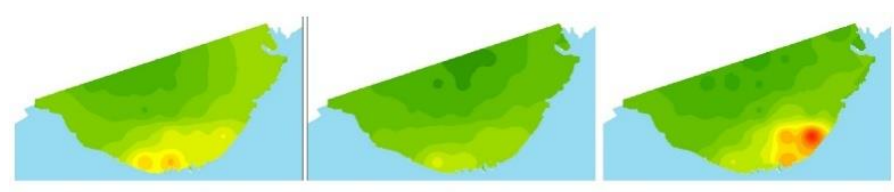

Juli $\quad$ Agustus $\quad$ September

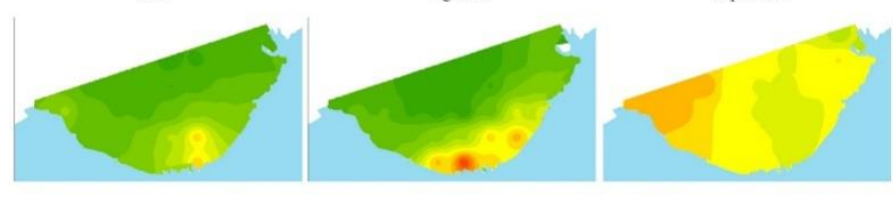

Oktober

November

Desember

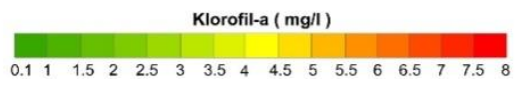

Gambar 2. Sebaran Spasial Klorofil-a klimatologi 2017- 2018

\section{Korelasi Bivariate antar Parameter pada Musim Barat}

Korelasi bivariate konsentrasi klorofil-a pada musim barat menunjukan nilai yang kuat dan berbanding lurus dengan kecepatan angin sebesar 0,742. Konsentrasi klorofil-a berkorelasi kuat dan berbanding terbalik dengan suhu permukaan laut sebesar -0,665. Korelasi bivariate konsentrasi klorofil-a menunjukan nilai yang sedang dan berbanding lurus terhadap curah hujan, salinitas dan TSS, dengan masing- masing nilai sebesar $0,521,0,302$ dan 0,359

Tabel 2. Tabel Korelasi Bivariate Klorofil-A dengan Parameter Pendukung pada Musi Barat

\begin{tabular}{|ll|c|c|c|c|c|c|}
\hline & & Klorofil-a & $\begin{array}{c}\text { Curah } \\
\text { hujan }\end{array}$ & TSS & Salinitas & $\begin{array}{c}\text { Kecepatan } \\
\text { Angin }\end{array}$ & Suhu \\
\hline Klorofil-a & Pearson Correlation & 1 & .521 & .359 & .302 & .742 & -.665 \\
& Sig. (2-tailed) & & .082 & .766 & .805 & .468 & .537 \\
& $\mathrm{~N}$ & 3 & 3 & 3 & 3 & 3 & 3 \\
\hline Curah & Pearson Correlation & .521 & 1 & .491 & -.904 & .565 & -.830 \\
Hujan & Sig. (2-tailed) & .082 & & .105 & .281 & .618 & .377 \\
& $\mathrm{~N}$ & 3 & 3 & 3 & 3 & 3 & 3 \\
\hline TSS & Pearson Correlation & .359 & .491 & 1 & .782 & -.360 & .329 \\
& Sig. (2-tailed) & .766 & .105 & & .429 & .766 & .229 \\
& $\mathrm{~N}$ & 3 & 3 & 3 & 3 & 3 & 3 \\
\hline Salinitas & Pearson Correlation & .302 & -.904 & .782 & 1 & -.863 & .512 \\
& Sig. (2-tailed) & .805 & .281 & .429 & & .337 & .658 \\
& $\mathrm{~N}$ & 3 & 3 & 3 & 3 & 3 & 3 \\
\hline Angin & Pearson Correlation & .742 & .565 & -.360 & -.863 & 1 & -.456 \\
& Sig. (2-tailed) & .468 & .618 & .766 & .337 & & .136 \\
& $\mathrm{~N}$ & 3 & 3 & 3 & 3 & 3 & 3 \\
\hline Suhu & Pearson Correlation & -.665 & -.830 & .329 & .512 & -.456 & 1 \\
& Sig. (2-tailed) & .537 & .377 & .229 & .658 & .105 & \\
& $\mathrm{~N}$ & 3 & 3 & 3 & 3 & 3 & 3 \\
\hline
\end{tabular}




\section{Korelasi Bivariate antar Parameter pada Musim Timur}

Korelasi bivariate klorofil-a dengan curah hujan, tss, kecepatan angin dan suhu menunjukan nilai yang sangat kuat dengan nilai masing-masing sebesar $0,866,0,743,0,844$ dan 0.822 . Korelasi bivariate klorofil-a dengan salinitas menunjukan nilai yang sangat kuat dan berbanding terbalik, dengan nilai sebsar $-0,75$.

Tabel 3. Tabel korelasi bivariate klorofil-a dengan parameter pendukung pada musim timur

\begin{tabular}{|ll|c|c|c|c|c|c|}
\hline & & Klorofil-a & $\begin{array}{c}\text { Curah } \\
\text { Hujan }\end{array}$ & TSS & Salinitas & $\begin{array}{c}\text { Kecepatan } \\
\text { Angin }\end{array}$ & Suhu \\
\hline Klorofil-a & Pearson Correlation & 1 & .866 & .743 & -.757 & .844 & -.822 \\
& Sig. (2-tailed) & & .334 & .007 & .004 & .361 & .386 \\
& $\mathrm{~N}$ & 3 & 3 & 3 & 3 & 3 & 3 \\
\hline $\begin{array}{l}\text { Curah } \\
\text { Hujan }\end{array}$ & Pearson Correlation & .866 & 1 & .755 & -.812 & .461 & .997 \\
& Sig. (2-tailed) & .334 & & .456 & .397 & .695 & .052 \\
& $\mathrm{~N}$ & 3 & 3 & 3 & 3 & 3 & 3 \\
\hline TSS & Pearson Correlation & .734 & .755 & 1 & -.996 & .930 & .699 \\
& Sig. (2-tailed) & .007 & .456 & & .058 & .239 & .507 \\
& $\mathrm{~N}$ & 3 & 3 & 3 & 3 & 3 & 3 \\
\hline Salinitas & Pearson Correlation & -.757 & -.812 & -.996 & 1 & -.893 & -.762 \\
& Sig. (2-tailed) & .063 & .397 & .058 & & .298 & .449 \\
& $\mathrm{~N}$ & 3 & 3 & 3 & 3 & 3 & 3 \\
\hline Kecepata & Pearson Correlation & .844 & .461 & .930 & -.893 & 1 & .388 \\
& Sig. (2-tailed) & .361 & .695 & .239 & .298 & & .746 \\
& $\mathrm{~N}$ & 3 & 3 & 3 & 3 & 3 & 3 \\
\hline Angin & Pearson Correlation & -.822 & .997 & .699 & -.762 & .388 & 1 \\
& Sig. (2-tailed) & .386 & .052 & .507 & .449 & .746 & \\
& $\mathrm{~N}$ & 3 & 3 & 3 & 3 & 3 & 3 \\
\hline Suhu & & & & & & \\
\hline
\end{tabular}

\section{Hubungan Klorofil-a dengan Kecepatan Angin}

Hasil korelasi pearson antara klorofil-a dan kecepatan angin yaitu 0,742 (Tabel 2) di musim barat dan 0.844 (Tabel 3) di musim timur yang korelasi nya berbanding lurus dengan tingkat hubungan yang tinggi. Seperti yang terjadi pada bulan Januari, yaitu kecepatan angin tertinggi sebesar 3,14 m/s (Tabel 1). Pada saat tersebut konsentrasi klorofil-a sebesar $2,95 \mathrm{mg} / \mathrm{m}^{3}$ (Tabel 1). Kondisi sebaliknya terjadi pada bulan Agustus yaitu nilai konsentrasi klorofil-a mencapai nilai terendah sebesar $1,85 \mathrm{mg} / \mathrm{m}^{3}$ (Tabel 1). Tingginya konsentrasi klorofil-a pada musim barat tampak terkait dengan kecepatan angin, tinggi kecepatan angin diduga menyebabkan proses pengadukan (mixing) yang kuat sehingga membawa nutrien dari lapisan bawah menuju ke lapisan atas, didukung dengan intensitas cahaya yang cukup maka pertumbuhan fitoplankton menjadi meningkat. Peningkatan pertumbuhan Fitoplankton tampak dari nilai Klorofil-a yang meningkat. Pernyataan ini diperkuat oleh Thorpe (2007), yang mengatakan bahwa pergerakan fluida secara vertikal yang dipengaruhi oleh angin di permukaan, mengakibatkan fluks nutrien dari lapisan bawah ke lapisan yang lebih atas. Hal ini menyebabkan proses percampuran memiliki peranan yang sangat penting bagi kehidupan fitoplankton untuk menopang pasokan nutrien yang sangat dibutuhkan untuk melakukan proses fotosintesis.

\section{Hubungan Klorofil-a dengan SPL}

Korelasi pearson antara klorofil-a dengan SPL bernilai - 0,665 (Tabel 2) pada musim barat dan -0.822 (Tabel 3) pada musim timur, yang berarti korelasi antar keduanya berbanding terbalik dengan tingkat keterkaitan yang kuat. Hal tersebut diduga karena semakin kencang kecepatan angin maka proses pengadukan massa air (mixing) semakin cepat sehingga massa air yang berada di lapisan bawah yang memiliki suhu rendah naik ke permukaan sehingga menyebabkan suhu permukaan menjadi rendah. Hal 
tersebut sesuai dengan pernyataan Kunarso et al. (2011), bahwa meningkatnya kecepatan angin Muson Tenggara akan menyebabkan meningkatnya intensitas upwelling yang berakibat pada meningkatnya aliran air dingin dari lapisan bawah ke permukaan.

\section{Hubungan Klorofil-a dengan Curah hujan}

Fenomena tingginya Kesuburan Perairan Teluk Semarang pada musim barat (Desember-Februari) diduga juga terjadi karena adanya peningkatan runoff sungai. Dugaan peningkatan run off sungai berdasarkan tingginya curah hujan pada musim tersebut dengan kisaran 8,61-19,95 mm/bulan (Tabel 1). Disamping itu dikuatkan juga berdasarkan hasil analisis korelasi (r) antara Klorofil-a dan curah hujan yang menunjukkan nilai sebesar 0,51 (Tabel 2) di musim barat dan 0.866 (Tabel 3) di musim timur. Adanya runoff sungai yang tinggi juga membawa nutrient yang tinggi dari daratan, hal ini menjadi sebab peningkatan kesuburan perairan yang memicu tingginya perkembangan produktifitas primer perairan. Pernyataan ini didukung oleh Kunarso et al., (2019) yang menyatakan, bahwa curah hujan (presipitasi) menyebabkan peningkatan run off sungai yang mengandung konsentrasi nutrient tinggi, yang hal tersebut dimanfaatkan untuk pertumbuhan fitoplankton. Lebih lanjut dijelaskan oleh Dahuri et al., (1996) bahwa, sungai sebagai media perairan untuk pembuangan limbah akan menyebabkan berkumpulnya bahan organik dari limbah tersebut, yang merupakan penyumbang unsur nutrien bagi perairan.

\section{Hubungan Klorofil-a dengan TSS}

Unsur hara atau nutrien yang terbawa run off sungai terikat pada material padatan tersuspensi. Tingginya runoff sungai pada musim barat juga tampak dari peningkatan material padatan tersuspesi (Total Suspended Solids/TSS). Bedasarkan Tabel 2 ditemukan korelasi antara Klorofil-a dan TSS sebesar 0,359 pada musim barat, dimana menunjukan korelasi yang sedang dan berbanding lurus, dan korelasi yang tinggi sebesar 0,743 (Tabel 3) pada musim timur. Semakin meningkat konsentrasi Klorofil-a diikuti dengan meningkatnya konsentrasi TSS dan juga sebaliknya. Seperti yang terjadi pada bulan Desember yaitu nilai konsentrasi klorofil-a mencapai nilai tertinggi sebesar 4,27 mg/m3 (Tabel 1) dan nilai konsentrasi TSS pada bulan tersebut juga tinggi sebesar $53,79 \mathrm{mg} / \mathrm{l}$ (Tabel 1). Material pembentuk TSS diantaranya terdiri dari pasir, lumpur, dan tanah liat atau partikel-partikel lain yang tersuspensi dalam air baik berupa komponen hidup (biotik) (contoh: fitoplankton, zooplankton, bakteri, fungi) maupun komponen mati (abiotik). Dijelaskan oleh Tarigan and Edward (2003), bahwa tingkat korelasi antara TSS dan Klorofil-a tampak berbanding lurus, hal ini diduga karena TSS yang terbawa dari daratan melalui runoff mengandung komponen abiotik berupa zat hara dari daratan yang berguna untuk fotosintesis Fitoplankton. Hal tersebut sesuai dengan pernyataan Pait et al., (2015) yang menyatakan, bahwa zat hara seperti Silika, Fosforus dan Urea yang melimpah terdapat pada sedimen di perairan tawar, selanjutnya terbawa ke laut, dimana pada daerah pesisir yang memilki pemasukan sedimen dan konsentrasi TSS yang tinggi, ditemukan pula jenis nutrien tertentu dalam jumlah yang besar, dan nutrien umumnya teradsorbsi ke dalam partikel sedimen.

\section{Sebaran Klorofil-a secara Spasial}

Hasil yang diperoleh menunjukan bahwa, konsentrasi Klorofil-a cenderung tinggi pada daerah pesisir seperti pada pesisir kecamatan Semarang Utara, Tugu, Genuk dan Sayung. Hampir setiap musim (FebruariNovember), konsentrasi Klorofil-a yang tinggi terdapat pada sisi selatan Teluk Semarang, dimana meliputi daerah yang cenderung luas di pesisir kecamatan Sayung kota Demak sampai kecamatan Tugu kota Semarang, dengan nilai kisaran konsentrasi sebesar 3,5-8 mg/m $\mathrm{m}^{3}$ (Gambar 2). Fenomena tersebut diduga disebabkan adanya aliran sungai besar yang bermuara di sepanjang Kecamatan Tugu sampai Kecamatan Sayung yaitu aliran air dari Sungai Banjir Kanal Timur, Sungai Banjir Kanal Barat dan Sungai Sayung. Aliran sungai ini diduga menyumbang nutrien yang dibutuhkan oleh fitoplankton untuk berfotosintesis. Hal ini didukung oleh penelitian yang dilakukan Qanita (2019) yang menemukan, bahwa distribusi kesuburan air 
di perairan Banjir Kanal Barat Semarang cukup tinggi dengan kisaran konsentrasi Klorofil-a sebesar 15-200 $\mathrm{mg} / \mathrm{m}^{3}$. Penelitian lain mengenai analisis sebaran Klorofil-a juga dilakukan oleh Dewanto (2015) di perairan kecamatan Tugu. Dinyatakan bahwa nilai kandungan klorofil-a di perairan tersebut menunjukkan kisaran 0,4076-4,1892 $\mathrm{mg} / \mathrm{m}^{3}$. Pada daerah tersebut persebaran klorofil-a secara horizontal dipengaruhi oleh kandungan nutrien (fosfat dan nitrat), dan terkait erat dengan proses fotosintesis. Daerah dengan konsentrasi tinggi klorofil-a lainya adalah pesisir Kecamatan Sayung, diduga disebabkan faktor geografis dimana pada daerah tersebut terdapat sungai sayung, Perairan Muara Sungai Sayung mempunyai karakteristik landai. Ekosistem estuari di kawasan muara Sungai Sayung Demak dikelilingi oleh pohon mangrove dan merupakan perairan yang sangat subur karena menjadi tempat penampung nutrient yang terbawa oleh sungai Sayung (Ulfah, 2012).

Konsentrasi klorofil-a yang rendah berada pada daerah yang menjauhi pantai hampir disetiap musim (Februari-November), dengan kisaran $0.1-2 \mathrm{mg} / \mathrm{m}^{3}$ (Gambar 2). Hal tersebut didukung oleh hasil penelitian Riyono et al., (2006) di Teluk Klabat, yaitu pola umum sebaran klorofil-a fitoplankton dan nutrien menunjukkan nilai yang tinggi hampir selalu ditemui di perairan yang relatif dekat dengan muara sungai, sedangkan di perairan yang telah agak jauh dari muara sungai kandungannya semakin rendah, terutama di teluk bagian luar.

\section{KESIMPULAN}

Nilai rerata bulanan klorofil-a di perairan Teluk Semarang berkisar antara 1,85-4,27 mg/m dengan Klorofil-a tinggi umum nya berada pada sisi selatan Teluk Semarang, yaitu daerah pesisir kecamatan Semarang Utara, Tugu, Genuk dan Sayung, dengan kisaran klorofil-a sebesar $4-8 \mathrm{mg} / \mathrm{m} 3$ yang rerata nilai klorofil-a tertinggi terjadi pada Musim Barat. Daerah dengan klorofil-a terendah umum nya berada pada sisi utara Teluk Semarang (mengarah ke laut lepas), dengan kisaran klorofil-a sebesar 0,1-1,5 mg/m3, dimana rerata nilai klorofil-a terendah terjadi pada Musim Timur. Klorofil-a memiliki korelasi bivariate yang kuat dan berbanding lurus dengan TSS $(0,743)$, secara kuat berbanding lurus terhadap kecepatan angin $(0,456)$, curah hujan $(0,506)$ dan secara kuat berbanding terbalik dengan suhu $(-0,665)$.

\section{DAFTAR PUSTAKA}

Adji, K. 2008. Evaluasi Kontaminasi Bakteri Pathogen Pada Ikan Segar Diperairan Teluk Semarang. Tesis, Program Pasca Sarjana Universitas Diponegoro Semarang.

Budhiman, S., T. Hobma and Z. Vekerdy. 2004. Mapping TSM Concentrations From Multi Sensor Satellite Images in Turbid Tropical Coastal Waters of Mahakam Delta Indonesia. ITC Enschade

Dahuri, R. 1996. Pengelolaan Sumber Daya Pesisir dan Lautan Secara Terpadu. Jakarta

Dewanto, W., A. Ismanto dan Widianingsih. 2015. Analisis Sebaran Horizontal Klorofil-a di Perairan Tugu Semarang. Program Studi Oseanografi, Jurusan Ilmu Kelautan, Fakultas Perikanan dan Ilmu Kelautan, Universitas Diponegoro, Jurnal Oseanografi. 2(4)366 - 378.

Hadi, S, 1987. Metodologi Reseach. Jakarta : Rineka Cipta.

Kunarso., A.., Irwani., A. Satriadi., M. Helmi., H. Prayogi and B. Munandar Wirasatriya. 2019. Impact of Climate Variability to Aquatic Productivity and Fisheries Resources in Jepara Waters. IOP Conf. Series: Earth and Environmental Science 246 (2019) 012021

Kunarso., S. Hadi., N. S. Ningsih dan M. S. Baskoro. 2011.Variabilitas Suhu dan Klorofil-a di Daerah Upwelling pada Variasi Kejadian ENSO dan IOD di Perairan Selatan Jawa sampai Timor. International Journal of Marine Science (IJMS). 16(3) : 171 - 180.

Pait, A.S, F.R. Galdo Jr, S.I. Hartwell, A.L. Mason, D.A. Apeti, C.F.G. Jeffrey, A.M. Hoffman, and S.J. Pittman. 2015. An assessment of nutrients, sedimentation, and total suspended solids (TSS) in the St. 
Thomas East End Reserves (STEER). NOAA Technical Memorandum NOS/NCCOS 184. Silver Spring, MD.

Pramono, G. 2005. Perbandingan Metode Trend dan Spline untuk Interpolasi Sebaran Sedimen Tersuspensi Di Kabubaten Maros, Sulawesi Selatan. Jurnal Ilmiah Geomatika 11(1): 20-32

Qanita, H., S. Subiyanto dan Hani'ah. 2019. Analisis Distribusi Total Suspended Solid dan Kandungan Klorofil-a Perairan Banjir Kanal Barat Semarang Menggunakan Citra Landsat 8 dan Sentinel-2a . Jurnal Geodesi Undip. 8(1).

Riyono, S.H., Afdal dan A. Rozak. 2006. Kondisi Perairan Teluk Klabat Ditinjau dari Kandungan Klorofil a Fitoplankton. Oseanologi dan Limnologi Indonesia. 39: 19-36.

Sarwono, J. 2006. Penelitian Kuantitatif dan Kualitatif. Yogyakarta. :Graha Ilmu

Tarigan, M. and S. Edward. 2003. Kandungan Total Padat Tersuspensi (Total Suspended Solid) di Perairan Raha, Sulawesi. Pusat Penelitian Oseanografi, LIPI, Jakarta. Makara Sains.7(3).

Thorpe, S.A. 2007. An Introduction to Ocean Turbulence. Cambridge: Cambridge University Press, $264 \mathrm{p}$ Ulfah, Y., Widianingsih dan M. Zainuri. 2012. Struktur Komunitas Makrozoobenthos di Perairan Wilayah MorosariDesa Bedono Kecamatan Sayung Demak. Journal Of Marine Research, 1(2): 188-196 